\title{
An East Timorese Domain
}

\section{Luca from Central and Peripheral Perspectives}

\author{
Susana Barnes* \\ Monash University, Australia \\ susanna.barnes@monash.edu \\ Hans Hägerdal \\ Linnaeus University, Sweden \\ hans.hagerdal@lnu.se

\section{Lisa Palmer} \\ University of Melbourne, Australia \\ lrpalmer@unimelb.edu.au
}

\begin{abstract}
The East Timorese kingdom Luca is described as the hegemon of the eastern parts of Timor in some nineteenth-century works. This is gainsaid by other data, which point to the existence of a multitude of petty kingdoms. This article scrutinizes Luca's claim to power from a number of angles, utilizing European records and contemporary anthropological fieldwork. First, we analyse the claims of the centre as reflected in colonial and indigenous narratives. Second, we investigate narratives from the 'periphery', that is, the minor adjacent domains of Vessoro and Babulo. Third, we offer a comprehensive discussion of Luca's role from a wider geographical perspective. In this way we produce a 'general account' that situates the symbolic and historical significance of Luca within the Timorese understanding of time, ritual, and power.
\end{abstract}

* We acknowledge all of those people within Timor Leste and elsewhere who so generously enabled, and contributed to, this research. In particular, we thank Balthasar Kehi for his translation of the ritual verse recounted in Tetum by the lia nain of Luca, David Amaral. Palmer acknowledges the Australian Research Council, which provided the necessary funds to carry out her long-term field research, and Hägerdal furthermore acknowledges the Concurrences research network at Linnaeus University.

(C) SUSANA BARNES, HANS HÄGERDAL AND LISA PALMER, 2017 DOI: 10.1163/22134379-17302020

This is an open access article distributed under the terms of the prevailing CC-BY-NC license at the time of publication. 


\section{Keywords}

East Timor - Luca - historiography - oral tradition

\section{Introduction}

The first half of the nineteenth century saw a great increase in academic explorations of lands brought under colonial domination. Distant places like Timor, which had so far received scant interest among geographers and botanists, came under intense scrutiny. In 1828-1829 the island was visited by the Dutch scientific traveller Salomon Müller, who wrote a verbose account published in 1839-1844. The author was well read in the natural sciences and ethnography, and his account and the accompanying illustrations display a sense for details not found in previous texts about Timor. Among all the illustrations of clothes, houses, weapons, and utensils, there is a map of western and central Timor. The various kingdoms of 'Dutch' Timor-most of them still hardly touched at all by European colonial attempts of control—are marked out with as much exactitude as was possible from the information available at the time. East of Belu, in the territory roughly corresponding to present-day Timor-Leste, is an extensive area of land denominated 'Loeka'. In his accompanying text, Müller confirms that Loeka, or Luca as it is presently spelt, dominated the eastern part of the island, but adds that its position did not exert any absolute power over the eastern peoples (Temminck 1839-1844:144). A contemporary observer, the Dutch commissioner Emanuel Francis, wrote in similar terms, but asserted that Luca was not a legitimate hegemon, but rather an area that had usurped power at an unspecified time in the past. ${ }^{1}$ The French traveller De Freycinet (1825:5334), on the other hand, asserted that Luca was the oldest of all princely houses, being recognized by a number of kings in the east.

Müller's, Francis's, and Freycinet's statements are entirely at odds with available Portuguese sources which, in contrast, mention close to $5^{0}$ reinos (kingdoms) in the Luso-affiliated parts of Timor. While the Portuguese colonial archives only highlight indigenous power structures in a patchy and incoherent way, they do not give us any reason to think that Luca would have had the least influence on other prominent kingdoms such as Maubara, Motael, SuaiCamenaça, Manufahi, and so on. In De Rosily's account from 1772, Vemasse,

1 Emanuel Francis, unpublished report about Timor, Koninklijk Instituut voor Taal-, Land- en Volkenkunde (KITLV) Archive, Leiden, H 548 (1832), f. 72. 


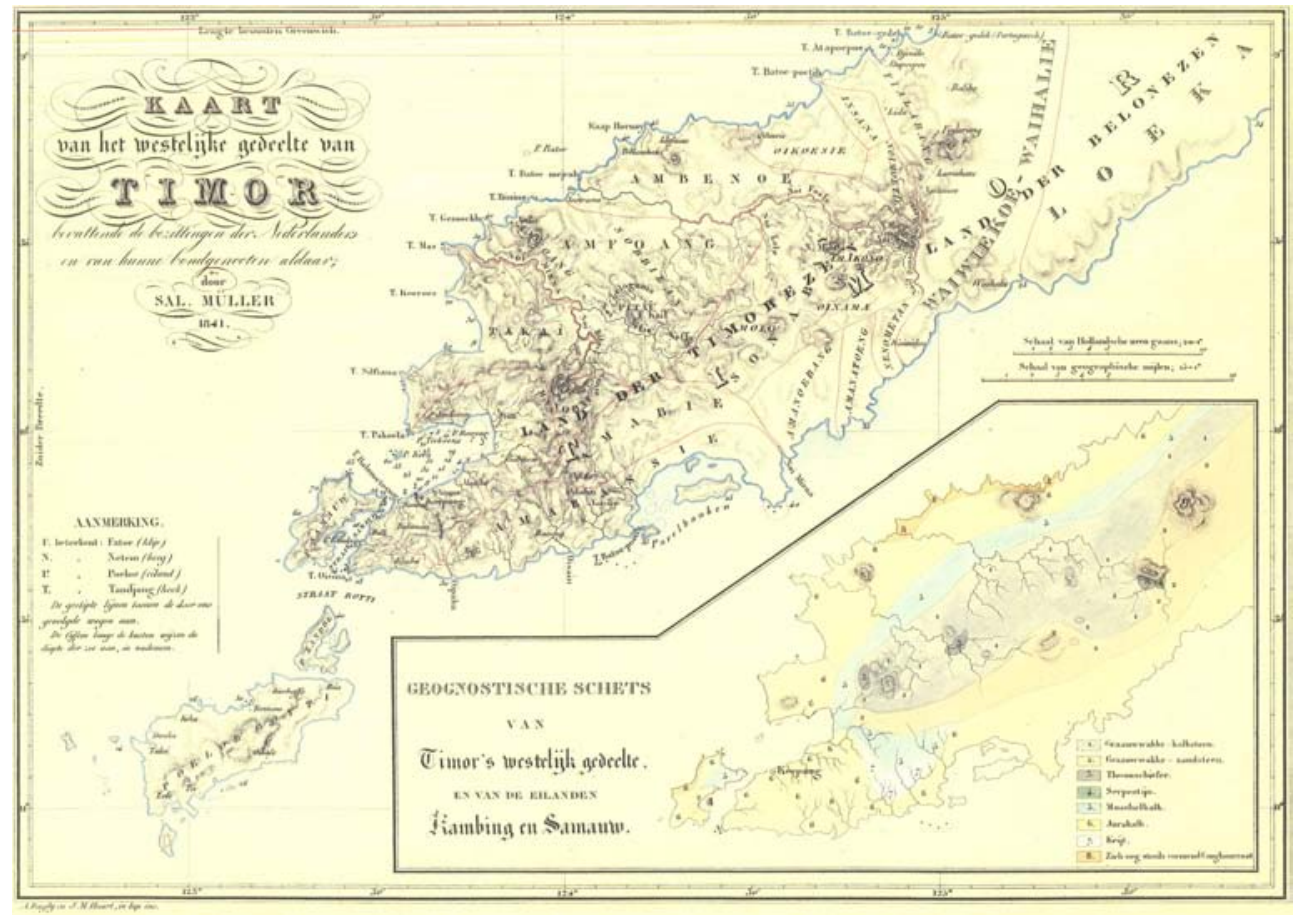

MAP $1 \quad$ Map of a part of Timor, in Temminck 1839-1844

Laleia, and Samoro are mentioned as the most important realms after the Black Portuguese stronghold Oecussi (Lombard-Jourdan 1982:93).

However, the story does not end there. In fact, the European nineteenthcentury accounts are closely paralleled by indigenous accounts from Luca itself-or rather, from the centre of the former reino. This in turn opens up interesting perspectives on the position and historiographic self-images of the traditional reinos of East Timor. How do the central historical traditions, and the central conceptions of statecraft, relate to perspectives of the margins, of areas which were claimed to be ritually or politically dominated by these central domains?

The Timorese tradition of statecraft must be studied in the light of the lively research on pre-modern Southeast Asian states that has emerged in the last half a century or so. Scholars such as Oliver Wolters, Benedict Anderson, Clifford Geertz, and Stanley Tambiah have developed so-called cosmic models of states which differ substantially from European notions. While early-modern and modern European states were characterized by relatively fixed borders and bureaucratic structures, Southeast Asian polities tended to have spatially disparate components. The state centre has been likened to a lamp whose 
light (power, influence) diminishes with the distance from the centre. Some of these models emphasize that the peripheral constituents tend to replicate the centre, so that outlying dependencies try to emulate the institutions and ritual practices of the central lord. A variant of this is the segmentary state model, according to which the constituents of a polity are structurally similar, so that their authority differs in extent rather than kind (Wellen 2004:7-8).

The aforementioned models are based on studies of Indianized kingdoms, and may not automatically translate to the small-scale Timorese domains, or 'kingdoms'. Anthropologists have described the variety of forms that these domains took, usually involving an elaborate hierarchy of genealogical groups with hereditary functions. In many cases, but not all, the central 'monarch' held the system in place by displaying deliberate inactivity. Here, a 'cosmic' model of rulership is combined with diarchical forms of governance, where the inactive, symbolically 'female' part is complemented by an active, 'male', executive regent (Schulte Nordholt 1971; McWilliam 2002). In recent years a number of studies have been conducted about Southeast Asian realms which have formed 'kingdoms of words' (to use Jane Drakard's term), meaning that they defy Western norms of political strength and have limited executive power, while still commanding a considerable amount of ritually laden prestige. What is more, their claims of authority outside their immediate borders, while not heeded in effect, have a degree of impact in the larger region. Such kingdoms of words include the central Timorese Wewiku-Wehali kingdom, the Minangkabau realm of Pagaruyung, and Dewa Agung's kingdom in Klungkung on Bali (Therik 2004; Drakard 1999; Wiener 1995; Geertz 1980). Thus Wewiku-Wehali, lying at the centre of the Tetun-speaking area (see Map 1), has a role in traditions all over Timor as a source of civilization, although it has never been a main player in Timorese politics since 1641-1642, at least not from the European perspective. In the same way, Pagaruyung was important in large parts of the Malay World, while Klungkung had a central position in Balinese understandings of the past.

From these points of view, Luca offers an interesting case for a study of the intersection between history and anthropology. Being situated in the eastern, Tetun-speaking area (see Map 1), it is accorded a great role in certain traditions and European accounts. Tetun is the lingua franca, or 'vehicular language', of central and most of eastern Timor, and may have been historically associated with advanced (from a European perspective) forms of culture and societal organization (Thomaz 1981). This might explain some of Luca's peculiar claims to authority. The present article combines a re-examination of textual sources with fieldwork in Luca and its neighbouring areas in order to explore two aspects of its perceived past. Firstly, we examine the central perspective, 
represented by indigenous spokesmen and reflected by European descriptions of Timorese politics. Here we wish to pinpoint the rationale of the claims to authority, and how the ambitions were visible in the colonial production of data. Secondly, we highlight how Luca was perceived by the periphery, areas which are claimed to have been included in Luca's sphere of authority. How do these constituents remember the ritual and political bonds, and when do they reject the claims of the centre? Do we find patterns that resonate with the cosmic models of states referred above, or with the kingdom-of-words model? Not least, how do narrative complexes, which invoke the custodianship of scarce water resources and the need to honour otherworldly relations with the sea, emerge as key themes in the history of Luca?

To pinpoint the perspectives taken by the historical elite of an East Timorese reino is methodologically cumbersome due to the scarcity of sources. In principle there are two ways to go about this. One can scrutinize the portrayal of the reino in European, mostly Portuguese, sources, and discern how it mirrors the way in which the elite wished to portray its own position in a local and regional setting. Alternatively, we can look at the oral traditions of recent times, long after the reinos ceased to have an important administrative function (c. 1912). Both ways are fraught with difficulties. The Portuguese letters and reports tend to be summary in their descriptions of local Timorese affairs, apart from their obvious bias and prejudice. As for oral traditions, a comparison between the versions recorded in both West and East Timor shows great variations depending on the spokesman. As we might expect, there seldom appears to be a 'master version' of the origins and history of a reino that is accepted and transmitted by the community (Traube 1989). That oral traditions in this part of Southeast Asia can sometimes contain reliable information (that is, according to otherwise ascertained data) can nevertheless not be doubted-one may refer to James Fox's studies of traditions on Rote off the western cape of Timor, which show a high degree of incidence between traditionally transmitted genealogical history and archival data, at least back to the mid seventeenth century (Fox 1971).

The oral histories from the periphery detailed in this article are based on long-term fieldwork (2005-2015) carried out independently by Barnes and Palmer. This research relied on ethnographic methods, including formal and informal interviews (in six local languages), as well as opportunistic observations and conversations with community members and frequent participation in a range of household, community, and ceremonial events. Drawing on this accumulated ethnographic record, we present and analyse what we understand to be key (mytho-)historical resonances echoing through the ritual domain of Luca. Our historical method for this retelling draws on our own and others' twentieth and twenty-first century ethnographic data to interpret par- 


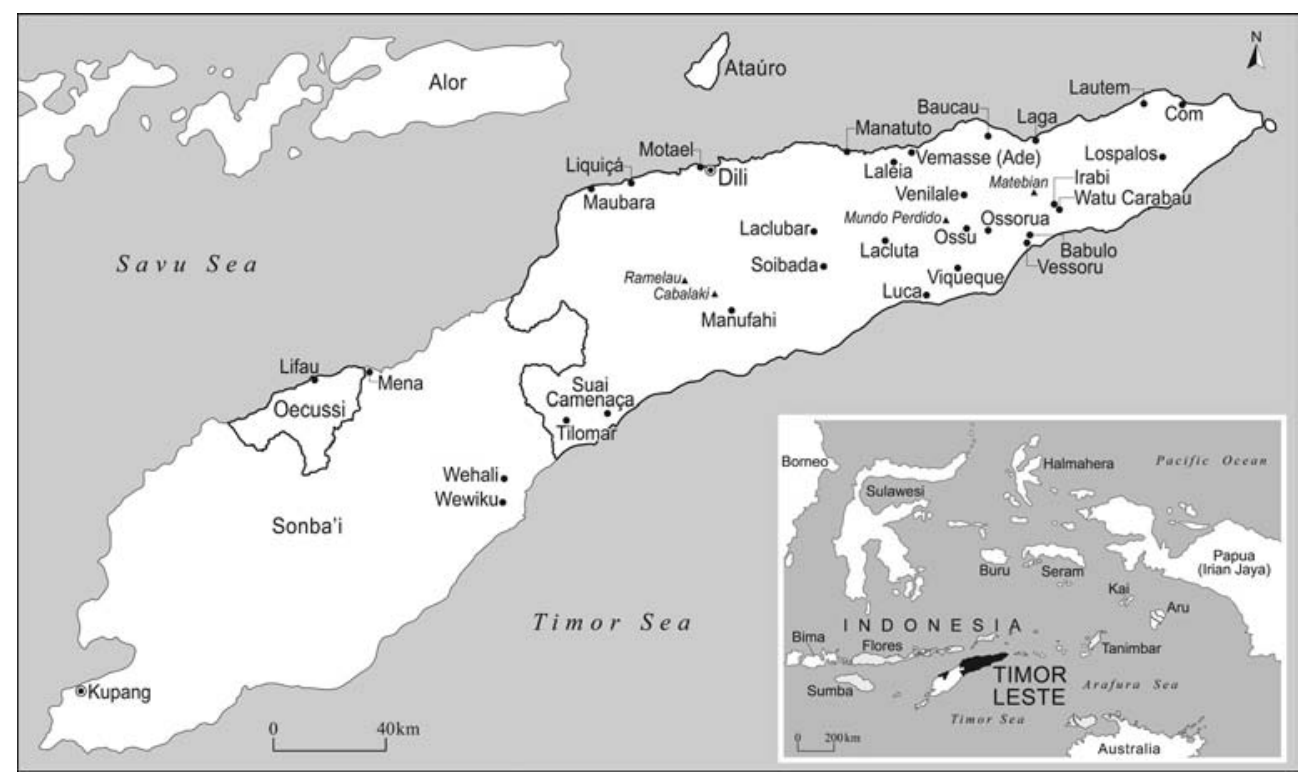

MAP 2

Map of Timor with the places mentioned in the article MAP DESIGN: CHANDRA JAYASURIYA

ticular mythic modalities and accompanying historical vignettes and conundrums. Our aim is to weave together our interpretations of our ethnographic data to produce a 'general account' (Gow 2001:23) of the regional significance of Luca and to then situate this within, and reinterpret, the wider historical archive. Yet, as will become clear, the narratives on which we rely are both contingent on history and on the context of their specific retellings (compare with Gow 2001:312; Bovensiepen 2012; Fox 1980; Traube 1989). Representing the past through 'a mix of history, memory and myth' these accounts are generative of place and relations over linear time (Attwood 2011:177). As we will see, these 'political' accounts are thoroughly interwoven with complex understandings of personhood, transgenerational immanence, and spirit ecologies that at their core involve a deep concern for the complex flow of relations enabled by water (Palmer 2015:60-82).

We divide our investigation into three sections. The first attempts to make sense of both oral and colonial records to trace the claims of the Luca elite to political and cultural-ritual centrality, including claims to be traditional suzerains of neighbouring realms, and even major parts of East Timor. This is followed by a section that discusses the perspectives of the minor adjacent domains Babulo and Vessoro. The third and final section provides a comprehensive discussion of Luca's role in a larger, regional perspective. 


\section{The Central Perspective: Oral Data}

The first comprehensive indigenous account of Luca, to our knowledge, is Peter Spillett's manuscript 'The pre-colonial history of the island of Timor together with some notes on the Makassan influence in the island' (1999). The section about Luca is based on nine interviews, mostly with members of the reigning Amaral family in 1994-1996. Spillett speaks in particular of a meeting with the 80-year-old liurai of Luca, 'still with a good recollection'. The liurai related to Spillett the origins of the kingdom, its relations to other groups, and a number of episodes from its purported past. Although the account was not entirely coherent, a few major characteristics can be pinpointed.

The uma lulik (sacred house) of Luca was at Kampung Badari, seven kilometres from Luca village. Most of its old heritage objects were destroyed in the civil war, and the Indonesians burned all the Portuguese books, papers, and letters. Nevertheless, Luca had once been an extensive realm, being superior to four minor kingdoms. These were: Loro Ossu-Hosoroa (Ossorua), Loro Besuru (Vessoro), Loro Wemassin (Vemasse), and Loro Waibobo. Furthermore, Wekeke or Viqueque was under the control of Luca, as was Takanar. A peculiar relationship existed between the eastern Tetun lands and the central Belu kingdoms. Luca was 'beneath' Wewiku and originated from Maromak, or 'God' in Wehali. This apparently alludes to the ritual rule of Maromak Oan ('son of the luminous') in Wehali, Wewiku's sister kingdom, which is known over almost all of Timor. An early ruling queen of Luca is mentioned as bestowing some of her land, Uatumuni (between Ossu and Viqueque), to Wewiku. The same queen would also have bestowed an heirloom in the form of a keke (bracelet) to Viqueque. Meanwhile, Viqueque had a special relationship with Wehali (Spillett 1999:300-1).

Spillett furthermore recorded a recitation in ritual speech about a meeting between Lu'u Leki, the Na'i Luka Likusan (ruler of Luca Likusan), and Bei Taek Aman, ruler of Wewiku. In this story the two counterparts meet at Kmodo Mahut Welaku and, after greeting each other, expand on their respective magical powers. Lu'u Leki has the capacity to command the reef to become dry and the sea itself to dry up. The ruler of Wewiku, on the other hand, decides that the sun and the moon set. Eventually Lu'u Leki concludes that the two kings are brothers who unite in their thinking 'like gold'. From their unity, strength and authority come forth (Spillett 1999:302-4). The implication is that they should share out the lands.

Noteworthy here is the double name Luka Likusan. Likusaen is also a kingdom that is formally identical with Liquiçá on the north coast, but is occasionally said to encompass Motael, close to Dili, or even Suai-Camenaça in 
the south. This in turn is intriguing, since Likusaen is sometimes characterized as the eastern component in a ritual tripartition of Timor:Wewiku-Wehali, flanked by the Atoni realm of Sonba'i and Likusaen. This is not a recent idea: there is a reference to the tripartition in a Portuguese document from 1734. At that time it was tied to anti-colonial revivalism, where an elevation of the three kings to their former position was expected to usher in a new era, free from foreign encroachment (Castro 1867:243).

Returning to the Spillett interviews, some particular data are provided about the later history of Luca. The arrival of the Portuguese is remembered without many details; it is only stated that their appearance was followed by fundamental political alterations: 'other kingdoms appeared and they cut off from Luka' (Spillett 1999:300). More is related about the affairs with the bishop of Malacca, a missionary figure who arrived in Badari with seven other Catholic priests, but came to a hasty end. In one version, the ruler does not want the services of the bishop and murders him when he enters the confessional box. In spite of this, the local population does not wish to return his remains to the Portuguese, but rather buries him in a secret place. Another version denies that the bishop was murdered (Spillett 1999:299, 301, 304). In fact, we do know from Portuguese records about a bishop of Malacca, Frei Manuel de Santo António, who stayed on Timor from 1697 to 1722 and was instrumental in Christianizing Luca, Viqueque, Samoro, Fatuleteluli, Alas, and Manatuto. This person, however, was not murdered, nor did he die on Timor. The complex of legends rather seems to embody the ritual intrusion of the Portuguese foreigners, and the resentment they evoked. ${ }^{2}$

This information from the 1990s is largely confirmed by an interview in 2014 with Clementino dos Reis Amaral, representative of the liurai family. He repeats the story of the meeting between the rulers of Luca and Wewiku and adds that the border between the two realms that was agreed on ran along the Mota Masin River at Tilomar in Suai. It may be added that a published account by Soares (2003), derived from the same family information, likewise depicts the territory of Luca as very extensive. Its borders would have stretched from Ue-Hedan across Rantau, Gunung Lihu-Wani, Laclubar, Cai-Mauc, Aitutu and Gunung Ramelau, as far as Suai. ${ }^{3}$

2 For Frei Manuel de Santo António, see Hägerdal 2012:316-35. The legend of a bishop of Malacca being buried in Luca is already mentioned in Visser 1934:162. A later bishop of Malacca, Geraldo de São José, died under suspicious circumstances in 1759/6o, but this seems to have occurred in Lifau rather than Luca; see De Matos 1974:76.

3 Soares 2003:45. Alor Island and Liquiçá are also sometimes linked with Luca in traditional accounts, as is Lautem. 
Amaral recounts a few stories about the early rulers of Luca. A king list is provided, starting with a certain Liurai Afoan Sila. ${ }^{4}$ His successor is Queen Na'i Lou Baria Sak, probably the female ruler spoken of in the Spillett interviews. She is here associated with the coming of the missionaries, who baptized her in Mena in present-day Indonesia. This is obviously paralleled by a passage in the Dominican chronicle, História de S. Domingos, which briefly states that António de São Domingos disseminated the true faith in Luca and baptized the queen, her minor son, her grandees, and innumerable people (De Santa Catharina 1866:298). Judging from other pieces of data, this event must have taken place in about 1670 (Teixeira 1957:448). The Amaral family tradition might have been influenced by Portuguese historiography, however.

Another theme added by Amaral is the break-up of the original bond between Wewiku-Wehali and Luca, which had provided strength for both rulers. Problems arose when the Luca ruler married a purportedly aristocratic woman from Wewiku-Wehali. After he had returned to Luca, it was discovered that his new wife was in fact a commoner with no royal blood. Exasperated, Lirai Luca sent his warriors to kill Liurai Wehali in retaliation for being deceived. Later on came the rebuttal, when Wehali in turn sent warriors to Luca and killed lots of people, including members of the royalty. Some refugees fled to present-day Vemasse on the north coast, including the liurai's brother. When the thirsty prince drank water from a well there it tasted salty. Therefore the place was called Vemasse, meaning salty water. ${ }^{5}$

There are some similar accounts in other sources. Soares (2003) speaks of a later queen called Dona Maria do Amaral, who attacked Liurai Wehali in 18321833, even though the latter was the central political figure of the Timorese hierarchy. The reason for this attack was due to concerns about the border and about religious proselytizing. The war was fought in the Suai area, where Suri Liurai of Wehali was killed and beheaded. The head of the great lord was brought in triumph to Badari, the centre of the Luca kingdom (Soares 2003:56).

The Amaral family tradition mentions several later events, corroborated by Portuguese data, and gives them a slant that enhances the importance of the central ruling lineage from an island-wide perspective. Perhaps inevitably, this involves the large Dom Boaventura rebellion in 1912, which did not directly affect Luca and has had a great patriotic significance in modern times (Davidson 1994:267-70). Local tradition provides an explanation for this non-

4 Curiously, Afoan is also synonymous Amfoan, an Atoni kingdom in West Timor that came under Dutch suzerainty at an early stage.

5 Clementino dos Reis Amaral, interview, February 2014. 
participation. In the early twentieth century, Dom Boaventura of Manufahi invited all the kings of Timor to rebel. Dom Lourenço Amaral ${ }^{6}$ told him via envoys: 'We endorse your invitation. But come and tell us when the time has come, that all is ready. Wear a special tais as a symbol that you are part of the movement.' However, as it turned out the forgetful messenger returned with the wrong symbol. Thus, Dom Lourenço thought that they might not be ready yet. Those of Luca nevertheless made it clear that the rebels were welcome to take refuge in Luca in case they lost. Formally, Luca was therefore not in the ranks of the Manufahista insurgents, in spite of having anti-colonial sympathies.

The tempests of World War II similarly made for a narrative that stresses the moral status of the Luca kingship. The story centres on Dom Jeremias dos Reis Amaral, who ruled as liurai in 1933-1943. He is fittingly described as a cheerful and straightforward person. When the Japanese invade, in 1942, he proves a loyal friend of Portugal. He actively protects the Portuguese in the Luca district and cooperates in the efforts to smuggle them to Australia. In that way he saves many lives, at the risk of his own well-being. Eventually the Japanese arrest Dom Jeremias, who is ill-treated and tortured. Notwithstanding this, he does not hand over any documents in his possession, nor does he tell his captors what he knows about the whereabouts of the Portuguese. He is killed by stabbing in 1943. Governor Óscar Freire inaugurates a monument to the martyred liurai in $1948 .{ }^{7}$

In sum, the central tradition of Luca provides us with a perspective that gives the small reino a much wider, explicitly Timor-wide significance. The rulers are the suzerains of neighbouring kingdoms, and are even considered to be the 'brothers' and equals of the central Wewiku-Wehali ruler. Occasionally they seem to include the amorphous but significant Likusaen in their domains, making them the most important lords in East Timor. Their involvement in border agreements and wars with Wewiku-Wehali, their rejection of the bishop of Malacca, the Dom Boaventura rebellion, and World War II seem to give the ruling lineage an importance vastly superior to what its modest territory would suggest. It is time to compare this late and factually unconfirmed picture with what can be gleaned from contemporary and near-contemporary records.

6 Perhaps this refers to Dom Clementino, who ruled at this time.

7 Clementino dos Reis Amaral, interview, February 2014. 


\section{Early European Records}

That Luca was a place of special importance is in fact borne out by some of the very earliest Portuguese records on Timor. The Malaccan geographer Manuel Godinho de Eredia drew the first detailed map of the island in 1613, and mentions 23 names along the southern and south-eastern coastline. Luca is the easternmost name, and the only one in bold letters (Durand 2006:80). De Eredia includes a passage about Timor in his geographical text 'Report on the Golden Chersonese' (c. 1597/160o). He makes a distinction between the 'emperors' of the northern and southern coastlands, namely those of Mena and Camenaça, possibly based on their commercial prominence in the sandalwood trade rather than any clear idea of indigenous Timorese power structures. But he also provides the important information that two rulers on the island had been approached by the Dominican missionaries and baptized. They were the 'emperor' of Mena and the king of Luca. Nevertheless, the triumph was shortlived: 'owing to the neglect of the latter [Dominicans], they turned Moors or Idolaters, as they always had been' (De Eredia 1997:254). That Luca, apart from Mena, is the only place mentioned as being sought out by the missionaries at an early stage, speaks for its significance in the eastern regions.

Unfortunately there is a long hiatus in the sources during most of the seventeenth century, when we hardly hear anything about Luca. The 'exploration' of Timor was guided by commercial and sometimes missionary concerns, and European or Eurasian activities were concentrated on the western and northwestern coastlands. It was only in the 166 os that the Tetun lands of the southeast briefly came into the limelight. The reason for this was the tripartite struggle for mastery over the north coast of East Timor between the Makassarese, the Portuguese, and the Dutch. In the face of the ravages committed by the Topasses (Black Portuguese) a voc official wrote to the headquarters in Batavia that the Portuguese had no valid claims to Ade (Vemasse) and Manatuto. Historically these lands were under the kingdom of Luca, a place at the 'eastern end' of Timor, and were the tributaries of this realm. A few years previously, however, they had defected from Luca. Later on, Ade and Manatuto flew the Dutch flag until the Topass fleets attacked and occupied these places in $1668 .{ }^{8}$

Little more is heard of Luca in the seventeenth century, apart from the aforementioned Dominican note that the ruling queen was baptized around the same time (De Santa Catharina 1866:298). The missionizing padre came from the recently established Portuguese base in Manatuto, perhaps suggesting that

8 Letter Kupang to Batavia 8-8-1668, Nationaal Archief (NA), The Hague, voc 2285, f. 179-8. 
the violent Topass onslaught did not fail to impress the local Tetun elite (Teixeira 1957:448). Other data indicate that the power of the Portuguese steadily expanded in the early 1670 s, as the squadrons rounded the eastern cape and proceeded along the south coast. The documents mention ravages of Suai, Fohoterin, Follafaik, Fatulete, and Leteluli in these years, but not Luca, so it may possibly have submitted voluntarily. ${ }^{9}$ Oral traditions found so far speak of a weakening of the kingdom with the coming of the Portuguese, rather than violent clashes.

From this extremely thin material it might be concluded that Luca was considered a kingdom with a much wider significance than its core area. Its alleged one-time vassals Ade and Manatuto were the key strategic places on the north coast of East Timor. It suggests a comprehensive political network, remembered in oral traditions that mention Vemasse as a vassal (but not Manatuto, as far as we have found, although Vemasse's jurisdiction is said to have stretched along the north coast, almost to Dili).

The Portuguese sources on Timor flow more steadily after 1702, when a regular governor, who was often in violent conflict with the Topass community, was established in Lifau. For most of the eighteenth century, however, there is even less evidence to indicate Luca's particular position vis-à-vis the neighbouring areas. Rather, the early-eighteenth-century documents emphasize the key role of Luca's supposed dependency Viqueque, which was the main support for the bishop of Malacca, Frei Manuel de Santo António, in his efforts to Christianize Timor (Leitão 1952).

\section{The War of the Mad}

The main event in Luca that made an impression on the Portuguese was the famous Guerra dos Doidos (War of the Mad), which raged from 1777 to 1785 and shook the power of the Portuguese at a time when they had recently moved their capital to Dili. Interestingly, the rising had strong millenarian features which may be compared with similar movements in other parts of the world - the Mahdists of Sudan, the Taipings of China, et cetera. In other words, grievances with a foreign or oppressive order recreated religious symbols, which translated into anti-foreignism and the promise of a better world. In Luca the rebellion centred around a 'prophet' who taught that the souls of the ancestors could be activated to fight along with the living against the

9 Dagregister Kupang sub 16-12-1673, NA, The Hague, voc 1301. 
Portuguese yoke. The rebellion was supported by the king at the time, Dom Sebastião Amaral. The unrest spread to several kingdoms in the region but was subjugated in the end by the usual means of chastisement- the destruction of settlements by pro-Portuguese forces. As a consequence Luca lost hold of Venilale, which became a kingdom of its own (Castro 1867:90-1).

For our purpose the role of the centre is intriguing. From the not always coherent information available, the king appears to have used a movement that originated from outside of the centre, driven by genuine popular displeasure with the Portuguese impositions. The movement in Luca was influential on a larger scale, as it tended to draw in neighbouring areas. Interesting is also that the rebel king of Luca managed to land on his feet and eventually made peace with the colonial power. From the perspective of Dili, the king was a useful figure on account of his influence in the eastern part of Portuguese Timor, echoing the wider importance of the Luca kingship hinted at in the 1668 source and in modern tradition. In a later incident in 1789 , the king made peace with anti-Portuguese rebels on his own accord, over the head of the governor, who grudgingly has to adjust (Castro 1867:95-9).

Moreover, the revivalism and anti-foreignism of the royal centre are clearly offset by the centrifugal forces that are at work. The (formerly?) subordinated Viqueque strengthened its position by siding with the Portuguese against Luca, and the Venilale domain was detached because of the troubles. The traditional prestige accorded to the royal centre could be activated under certain circumstances in order to pursue an expansive policy, but the realities of the immensely complicated political game of Portuguese Timor soon exhausted the resources of the little kingdom.

\section{Pride and Poverty}

In fact, Luca did not make much of an impression in the Portuguese records of the nineteenth and early twentieth centuries. In spite of a history of Catholic missionizing since the late sixteenth century, there were no more than 15 Christian souls there in 1856-many fewer than in the other major kingdoms (Pélissier 1996:37). On the eve of the Japanese occupation, in 1942, a certain Carlos Cal Brandão volunteered his far-from-flattering impressions of Luca, which was considered a conservative and backward place by colonial standardsindeed the anathema of the claims of a glorious past that it cherishes. As he wrote, Luca was the poorest place on the otherwise rich and resourceful south coast. It was only along the banks of the rivers and in rare clearings in the woods that one encountered small rice fields or simple cornfields. The low 
TABLE 1 The House of Luca according to local information. The dates are partly debatable. The list omits a number of documented rulers: Sancho Manuel fl. 1738, Anna do Amaral fl. 1815, Felix António do Amaral fl. 1817, João de Amaral fl. 1854, Luíz dos Reis e Cunha fl. $1869-1876$.

Liurai Afoan Sila [supposed to have reigned before

the coming of the Portuguese to the region in 1512]

Liurai Feto Na'i Lou Baria Sak [queen, baptized in Mena in '1644']

Liurai Na'i Lequi Sak

Liurai Na'i Lulequik I [encounter with Wewiku]

Dom Sebastião Fernandes 1703-1726 [emperor of Wehali residing in Luca]

Dom Matias da Costa 1726-1731

Dom António Aveiro Amaral 1730s-1769

Dom Sebastião da Costa Amaral 1769-180o

sibling

[led the War of the Mad; emblematic

Luca king in local traditions]

Dom Tomás Amaral I 1800-1826

[self-willed policy vis-à-vis Portugal]

Dona Maria Amaral 1826-1850 [warfare against Wehali 1832-33]

Liurai Na'i Lulequik II 1850-1880

sibling Dom José Amaral 1880-1885 m. Dona Rosa Amaral 1885-1900

Dom Clementino dos Reis Amaral

1900-1914 [Dom Boaventura Rebellion] ।

Dom Tomás dos Reis
1914-1917, 1923-1926

Dona Ipifania

m. Paulo Guterres

1959-1989

Francisco Guterres 1989-
Dom Lourenço Amaral

1917-1923, 1926-1933

Zeferino Amaral 1944-1959

Domingos Torrezão dos

Reis Amaral 1979-1989<smiles>C1CCCC1</smiles>

Dom Jeremias dos
Reis Amaral 1933-1943
[martyrdom, Japanese
occupation]

Dom Jeremias dos
Reis Amaral 1933-1943
[martyrdom, Japanese
occupation]

Dom Jeremias dos
Reis Amaral 1933-1943
[martyrdom, Japanese
occupation]

occupation]

sibling 
population density was aggravated by the alleged indolence of the population. They seemed to be living on the traditions of a glorious past, and the pretension of descending from the foremost aristocracy on Timor (Belo 2013:329).

\section{Babulo and Vessoru - Traces of Luca on the Southern Coast}

While the historical and oral sources cited above produce intriguing accounts of Luca from the perspective of the 'centre', the colonial encounter, and its attendant history-making on the island, what is missing from the picture are the stories that are told and retold in particular contexts by 'non-centre', or periphery, communities related to Luca. As is common in Timorese oral accounts, these localized oral histories demonstrate a frequent preference for cyclical time and a preoccupation with identity, relationships, and hierarchy (Schulte Nordholt 1971; compare with Hägerdal 2012:10-13). Yet it is clear that within the recurring motifs of local narrative genres, vibrant oral accounts of place and place-making contain highly localized and nuanced interpretations of the significance of Luca as a pre-colonial and colonial centre of ritual and political power (Palmer 2015:39-60).

While historians and anthropologists have long written on the subject of the great western kingdom of Wehali ${ }^{10}$ and its relation to other major ritual centres, here we will give accounts of Luca which emanate from its peripheries. The material demonstrates clearly both Luca's pre- and early colonial ritual power and cosmological force as well as its changing role and fate during the colonial era.

Traces of Luca can be found throughout the landscape of Eastern Viqueque, including the suku of Babulo located in Uato Lari sub-district. Today, Babulo has a total population of 4,351 (Census 2010), the majority of whom are Naueti speakers. A minority ( $25 \%)$ of inhabitants of Babulo are Makassae speakers, and a number of individuals and families are of mixed linguistic heritage. Babulo is divided into eight hamlets, or aldeias: Lia Sidi, Abadere, Asa Muta, Aha Bu'u, Kota Nisi, Roma, Beli, and Daralari. These hamlets broadly correspond to an 'origin group', sharing a common ancestor (either through real or fictive descent) and centred on a common sacred house. Five of these hamlets-Beli, Daralari, Aha Bu'u, Kota Nisi, and Roma-form the core of a distinct ritual domain (N: rea luli) known as rea luli Ina Ama Beli Darlari / Babulo Mane Hitu (Mother, Father Beli Daralari/Seven Brothers of Babulo), which is centred on the

$10 \quad$ Therik 2004; Francillon 1967; Schulte Nordholt 1971; Hägerdal 2012; Gunn 1999; Soares 2003. 
principal sacred houses of Daralari hamlet, the Uma Buti (white house) and Uma Ita (black house) located at a place called Uato Soba on Baha Liurai ('the king's mountain'), approximately $2 \mathrm{~km}$ from the old posto at Uato Lari Leten.

Accessible written historical or secondary sources that directly mention Babulo are few and far between. Sustained Portuguese presence in the area did not occur until the early twentieth century, and even then it was mostly in the form of mestizo Timorese-Portuguese civil servants, itinerant missionaries, or military (Gunter 2008; Pélissier 1996). Available colonial records and local historical narratives do, however, appear to support the hypothesis that the suco (village) of Babulo, as we understand it today, is a relatively new configuration that emerged as a result of strategic alliances between local groups and the colonial authorities. In the colonial gazette Boletim de Timor, the suco of Babulo only begins to be regularly listed as a part of the posto of Uato Lari after $1934 .{ }^{11}$ Prior to that, most records refer either to the suco of Lia Sidi or the reino of Vessoru.

From the May 1910 bulletin we learn that the chefe suco (village chief) of 'LiaCide' was removed for 'disobedience' and replaced by the indigena (Portuguese colonial category of 'indigenous') 'Mau Gai', Mau Ga'e, or Mau Gai being a named ancestor of the origin house of Aha Bu'u. The chiefs of Babulo have historically been 'chosen' from a clan called the Burmeta, either from the lineage of Aha Bu'u (descendants of Mau Ga'e) or from the lineage of Kota Nisi (descendants of Kai $\mathrm{Du}$ ). Although there are conflicting narratives as to the origins of the Burmeta, several interlocutors from Babulo suggested that they were a warrior clan (т: asuwain) from the eastern part of the Matebian range who were 'rich in people, not in land. ${ }^{2}$

Oral histories from Babulo that recount the arrival of the Burmeta to the area involve elements of the myth of the 'stranger-king' and the related theme of 'the outsider installed on the inside', which serve to legitimize the authority of an external ruler over an indigenous population (Fox 1995; Sahlins 2008) and in this instance establish the basis for diarchic social organization. Fearful that the Burmeta warrior clan might swear allegiance to their powerful neighbours in Luca, the local rulers from the Beli/Daralari origin group negotiated a juramento $(\mathrm{P} / \mathrm{T}$ : oath) with the newcomers, and granted them some land in

11 The posto of Uato Lari itself appears only to have been created in the mid 1910s, when Tomas dos Reis Amaral (from the royal family of Luca) was made regulo (ruler) of Vessoru and administrator of Uato Lari.

12 Personal communication with Jose Trindade 26-11-20o6. Eight generations back roughly corresponds to 200 years ago. Other sources suggest that the Burmeta were exiled from their own land east of Matebian for raiding cattle. 
exchange for protecting the people and borders of their domain ( $\mathrm{N}$ : lai renu, lai rea). The nature of this juramento, which was a blood oath, is considered luli ( $\mathrm{N}$ : sacred), and is regularly invoked as the basis of ritual and political relations between the descendants of the Burmeta and Beli/Daralari. While the Beli/Daralari ancestors retained ritual authority over the domain, and were responsible for the continued fertility and prosperity of the land and its people, the Burmeta became the local political leaders.

It seems, however, that the Burmeta did not limit themselves to entering an agreement with the Beli/Daralari ancestors, but also made strategic alliances with other house-based groups in the area, including those of Lia Sidi. They emerged as political rulers with jurisdiction over a number of different, preexisting groups and politico-ritual configurations.

The obligation to protect the borders of the domain over time included responsibility for relations with external actors and, in particular, the colonial state. As holders of jural (executive) power in the area, the Burmeta were likely the first point of contact with the colonial authorities (Gunn 1999). Although it is difficult to date, the Portuguese are said to have granted the title of Tenente Coronel to the head of the Burmeta clan, who was also given a rota (traditional baton or 'sceptre' made of wood, usually tipped with metal hubs) 'from Viqueque' as a symbol of office to rule (т: ukun) over the people of Babulo. ${ }^{13}$

While the first suco chiefs may have been chosen from the lineage house of Mau Ga'e, this does not preclude the possibility that a kingdom or chiefdom preceded the colonial-era configuration. One reading of the available historical material suggests that a 'chiefdom' or 'kingdom' of Babulo may have existed as far back as the 16oos, and was under the direct vassalage of Vessoru.

Colonial records of Vessoru date to the late seventeenth century. In 1698 Vessoru was one of the kingdoms visited by the Dominican missionary Padre Frei Manuel de Santo Antonio, who later became the bishop of Malacca (Belo 2013:245). Vessoru remained a vassal kingdom under the jurisdiction of Luca throughout the eighteenth and nineteenth century (Belo 2013; Pélissier 1996). The kingdom of Vessoru is said to have encompassed much of the coastline, possibly stretching as far west as Beasu, to Iliomar in the east (Da Silva 2004).

13 It is unclear whether this rota came from the reino of Viqueque, which in 1891 stretched as far as Matebian, or whether this is in fact one of the 'indigenous' rota granted by the kingdom of Ai-Sahe (Viqueque) to which Babulo paid a harvest tribute (Spillett 1999). It may be the case that the kingdom of Ai-Sahe, which later became Viqueque, acted as a 'proxy' for the Portuguese. 
Through its relationship with Vessoru, Babulo was connected to Luca, and possibly the ritual centre of Wehali, by a tributary system of ritualized harvest offerings (Belo 2013; Therik 2004; Forman 1978). ${ }^{14}$ In Tetun Terik, the dominant language on the southern coast of Timor island from Wehali-Wewiku to east of Vessoru, the term babulo means 'chiefdom' or 'kingdom' (Panão 1920). ${ }^{15}$ Vestiges of this relationship with Vessoru and Luca remain to this day in the form of material objects, personal and house names, oral histories, and genealogical links.

Members of the senior houses of Aha Bu'u and Daralari are related to the former rulers of Luca, and there are two houses in the hamlet of Beli that are directly linked to Luca through oral histories. The house of Uma Timor (Mou Kai, Uani Kai) 'received' representatives from Luca who came to collect tribute. The house of Uma Malae (Kai Bira, Kar(a) Soru) was the kusu selu (saddle house) and resting place for representatives from Luca. One informant also suggested that the red-and-black cloth that distinguishes women from the highranking core origin groups of Babulo, called krabi wa'e mae, was also symbolic of the relationship with Luca. Wa'e means to cradle something protectively in one's arms like a baby, and mae means red, symbolizing blood and fertility (see also Hamilton and Barkmann 2014). ${ }^{16}$ Josh Trindade, of Aha Bu'u, suggested to Barnes that the woven cloth figuratively represented the protective and encompassing nature of relations between Luca and Babulo. Senior houses of the Daralari origin group and the house of the former liurai of Babulo, from Aha Bu'u, are both related to the Luca liurai family of Clementino dos Reis Amaral through marriage-although members of these houses cannot recall how far back these alliances date.

Yet, these vestiges of knowledge of a primarily political alliance between the chiefdom of Babulo and Luca, by way of the kingdom of Vessoru, are intertwined with oral accounts that suggest a deeper level of relations and resonate with other histories collected on the southern coast and in the BaucauViqueque area (Palmer 2015).

In the oral narratives of the Daralari custodians of the land of the ritual domain of Ina Ama Beli Daralari, which is centred on the holy mountain of Baha Liurai in Babulo, there is a dove-tailing of mythical and historical time.

14 These same alliances may have also tied Babulo to tributary networks directed towards the Portuguese authorities (see Roque 2010).

15 We are indebted to Balthazar Kehi, who first pointed out this meaning to Barnes, and later Janet Gunter for identifying Panão as a historical source mentioning Babulo in relation to Vessoru and Luca.

16 Personal communication with R. Hamilton and J. Trindade 28-3-2014. 
According to one narrative the people of Vessoru were descendants of a 'younger brother' of Luca who came to the area in search of land. At the time of their arrival the founder-ancestors of the domain, the Mane Hitu (seven brothers) were at war with a neighbouring kingdom called Builó (located in present-day Ossorua). The ancestors asked the leaders of Vessoru to help broker a lasting peace with their enemy and granted them some land on which to settle in recognition of their role as peacemakers. Elders from Babulo claim that this land, which is located between two rivers, Bee Lia and Bee Saketo, was never fully relinquished to the people of Vessoru, but access was secured by virtue of a marriage. One of the female ancestors of the domain was betrothed to the dom of Vessoru. She was expressly tasked with watching over two springs, bee matan Saketo and bee matan Lobuto, thus becoming the custodian of the water (т: bee nain, N: wai bu'u). ${ }^{17}$ This role has been passed down from the mother to her sons and their descendants.

This, however, was no ordinary betrothal and marriage. In oral histories from both Babulo and Vessoru, the 'younger brother' of Luca who becomes the dom (Portuguese title given to local rulers) of Vessoru, is the 'king of the underworld' (liurai rai okos) and the Beli/Daralari female ancestor is the 'eldest sister' (sometimes daughter) of the Mane Hitu founder-ancestors. This story resonates with oral narratives found across the southern coast and the BaucauViqueque region, where Luca's relationship with local populations is secured through the medium of water and consolidated through marriage.

The current dom of Vessoru, who inherited the title from his father, who died in 2004, recounts the history in these words:

Nai Mesak (the sister or female descendant of the Seven Brothers/Mane Hitu) goes to fetch water at the spring of Bee Lia. ${ }^{18}$ At the spring Nai Mesak collects water and then returns home. Once home, she realizes she has left her hairpin (ulu suku) at the spring; so Nai Mesak returns to the spring to look for her hairpin. At the spring she looks everywhere, but cannot find it. Suddenly, a green-yellow fish (ikan modok) appears and asks Nai Mesak, 'What are you looking for?', to which Nai Mesak replies: 'I am looking for my hairpin'. The yellowish fish says, 'Your hairpin disappeared in the

17 As descendants of the custodian of the water, the rulers of Vessoru are believed to have special power over all creatures that live in the water, in particular eels and crocodiles. When the former dom of Vessoru, Humerto, died in 2004 it was reported that four crocodiles appeared in the creek near his home and 'mourned' for four days.

18 According to Beli/Daralari narratives, this is the sister (sometimes the daughter) of the Mane Hitu founder-ancestors. 
water'. Then Nai Mesak disappears into the underworld; she does not die, but instead marries a liurai (king) — the king of the underworld.

Nai Mesak's servant looks for her all day, but cannot find her. That night her servant dreams that Nai Mesak has married the king of the underworld. In her dream, the servant looks for Nai Mesak and finds her at the side of the king of the underworld as his queen. The king of the underworld tells the servant: 'Your king and Nai Mesak cannot return. So go and tell your liurai (ruler/king) to make a buffalo enclosure'. The servant returns to tell the liurai. With great sadness, the liurai and his servants do as the king of the underworld has asked. They work for seven days, then one night at around nine o'clock a buffalo call emerges from the spring, followed by red, black, and striped (makerek, 'colourful') buffaloes, one after another. The last one to come out of the spring carries a golden disc (belak), glass beads (morten), and a sword (surik) attached to its horns. The liurai sees that this is enough (exchange goods for his sister) and with a wooden stick he stops the flow. After the buffalo emerged from Bee Lia, the liurai prepared an enclosure called Tapalu. Now people live there.

\section{Luca from the Periphery}

As we have started to see above, across the eastern part of Timor Leste Luca's central, political, and ritual power is continually encoded in the periphery through myth and narrative. It is clear that much of this narrative material is associated with springs, which are in turn connected to various local houses. Indeed, further down the south coast, in Watu Karabao, the narratives relating to the spring waters of Irabin have much in common with those recounted in the Vessoru and Babulo story of Nai Mesak. Moving inland, the people of the mountain kingdom of Ossu also narrate stories of their springs, which relate and connect them to the power of the waters of both Luca and Irabi. ${ }^{19}$ The custodian of the water in Irabi, Armindo da Silva, asserts a long-standing connection between the kingdoms of Luca and Irabi. He maintains that a younger brother of Luca came into an alliance through marriage with the people of Irabi long before the Portuguese set foot on the isle of Timor. As we will see below, these trails of connection also stretch to the north coast of Baucau. Taken in combination, we argue that they provide evidence of a certain

19 See Palmer 2015; see also www.kulturatimorhobee.com (accessed 29-05-2017). 
kind that Luca was once the great kingdom of the east, a kingdom whose power was activated by a widespread belief in its particular ability to communicate with the ancestral power of the underworld.

As with Luca's paired ritual counterpart Wewiku-Wehali, it is important to stress the fact that this domain is as much a ritual-political concept or symbol as it is an actual political realm (Francillon 1967:113). Schulte Nordholt (1971) argues in relation to Wehali's regional power that this relatively dynamic and open system of politico-ritual power was in fact held together by mythic accounts of the power of the centre (an immobile core of ritual power and skill). It was the ritual connections of the immobile centre to surrounding emissary sub-kingdoms which held the domain together. While, as with Wehali (ET: banyan tree water), the political importance of Luca has long since declined, we show below that its symbolic meanings and its encoding in ritual form remain central to many mythic narratives across the region. In many of these narratives it is Luca's power to communicate with the sea (and, through this, its capacity to access the wealth of the underworld) that remains a recurring theme. ${ }^{20}$ Because of its once pre-eminent politico-ritual presence in the region by virtue of its power to tame the sea, Luca is understood as the pre-eminent communicator with rai seluk (the other world) (Palmer 2015:39-60).

There is, as we have seen, much in the oral history record which links Luca to the expansion of the kingdom of Wewiku-Wehali. Yet even these accounts of early statecraft suggest an earlier, less formalized connection between peoples in the east and those migrating out from the Belunese heartland of Wehali. According to such accounts, Luca was linked to Wewiku and Viqueque (formerly the Waima'a-speaking kingdom of Ai Sahe) was linked to Wehali. Spillett recounts a narrative in which 'Sorai (Sau Rai) Dasa Rai was the first man to clear the land in Luka [...] There were no boundaries it was all open land. When the three Datos or Lords arrived from Wewiku-Wehali they brought the first Ai Hali or Banyan tree' (Spillett 1999:351). From this point, as we will see, the power of Luca grew and spread across the east. While Luca is often correlated with Portuguese colonial power, others assert that '[b]efore the Portuguese monarchy Luka was a very large Kingdom' (Spillett 1999:300).

Meanwhile, others in Luca and in the domain of Wewiku-Wehali have their own origin narratives, which precede the arrival of rulers from this domain. In the case of both kingdoms counter narratives come from speakers of older languages in the area (Makasae and Waima'a in the East and Melus (Atoni) and

20 As for Luca's wealth (usually expressed as buffaloes and gold) and power over the sea, Hicks (2004:66) notes that Lu'u Leki, the ruler of Luca, was said to own much gold. 
Mountain Tetum in the West (compare with Francillon 1967:150-1; Spillett 1999; Palmer 2015; Kehi and Palmer 2012)).

In a manner which suggests a convergence with autochthonous origin narratives from the east, in Luca the lia nain (custodian of the words) of the ruling house Uma Kan Lor, David Amaral, relayed to Palmer a narrative concerning seven siblings who emerged from the earth. These seven siblings commenced tilling the land ( $\mathrm{T}$ : fila rai) around Luca, which until then had had neither fields nor water. As a consequence of there being no water, the youngest brother was continually bullied into fetching water from the west and east of the island. One day, as the youngest sibling sat exhausted under a banyan tree, he cried that it would be best if he took his own life. Yet, as he spoke, water started to gush beneath his feet. Later the older brothers arrived to see that their youngest brother had morphed into water from the chest down. The boy, whose name was Nai Leki, told his older siblings that he had transformed into the sacred spring of We Lolo. ${ }^{21}$ His head then transformed into a water bowl (т: we lolo) and lodged in the banyan tree now called Nai Leki. This spring water flowed from We Lolo to the sea, passing the sacred tidal lagoon of Luca called We Liurai (Т: ruler's water). Luca became a kingdom of seven villages and a centre of power. Meanwhile these sacred-origin waters of Luca are known metaphorically as we ai balun (T: wooden-safe water), as it is from these waters that the wealth of Luca has been distributed across the land.

It is clear from mythic narratives found across the region that it is to Luca that people have long travelled to receive, or travelled from to decree, the power to rule. Following a ritual ceremony at the springs of Luca, emissaries would leave as the kingdom's 'arms and legs' (т: ain liman) and execute the authority of the ritual centre across the east. Through this process, Luca's sacred waters would be carried across the region to create child or subsidiary springs. According to a ritual leader in Baucau, Major Ko'o Raku, at some point after the emergence of dry land from a world of water, the first people of what is now Baucau descended from the central peaks of the Mundo Perdido range. Two of these people, a husband and wife, arrived in Baucau, where they found themselves in a land bereft of water. So that they might be able to live in this place, the husband set off for seven days and seven nights and returned to his wife with a bamboo cylinder (Waima'a: $a e$ ) full of sacred water from the kingdom of Luca. He threw down the water between his wife's legs and a spring spewed forth from the ground. This man took on the name of Wai Lewa, ${ }^{22}$

21 In another version of this story the main protagonist is a woman.

22 On account of his posthumous baptism, he is also known as Fransisco Wai Lewa. 
and he became the founding father of Baucau, which was known then by the name of its spring Wai Lewa (w: lewa, 'garden'). Similarly the Waima'a-speaking custodians of the related spring complex of Wai Husu in nearby Teolale also record that their ancestors arrived from Luca, but in this case in the form of an eel, which emerged from the spring and transformed into a woman. Ritual verse from the village of Wani Uma records the arrival of the Kingdom of Luca in the spring grove of Teolale:

Viqueque Luca mai Luca Tirilolo Viqueque Luca comes to Luca Tirilolo Teolale Lumu Lumu Teolale is all green

Koi Kota Daru And the stone walls are made

The Luca lia nain's account of the kingdom of Luca, and its spread across half the island, correlates with many of these spring narratives:

Ukun atu tun, bandu atu natiha

Kona ba bua, kona ba nu, kona ba we, kona ba namon (tasi).

Nee koalia naake:

We Daer Kan Lor.

Dato Hat.

Loro Hat.

Noda Asu Ikun Nain.

Namoro Nain.

Noda katuas uma kain lima:

Bei Olo, Bei Leki, Bei Lu,

Bei Toi, Bei Kai.

Noda nia oan, noda nia alin.

Suku Luka nia naran.

Fafulu We Mali.

Kesi Kilat Sama Lari

Fatua Loi Hunu.
The laws are coming down, the forbidden rules are being given from above. Concerning the betel nut, the coconut, the water and the sea.

We speak like this:

The realm of We Daer Kan Lor has

four kingdoms

four dominions

They include the guardian of Asu Ikun The guardian of Namoro [Samoro?]. They include the ancestors of five communities:

Bei Olo, Bei Leki, Bei Lu, Bei Toi, Bei Kai.

They include their children and siblings The names of the clan of Luka:

Fafulu We Mali.

Kesi Kilat Sama Lari

Fatua Loi Hunu.

Noda ba postu seluk koalia katak: They include other districts, as it is told:

Ossu Ossu Rua.

Ossu Ossu Rua.

Bui Lale Kai Wai Ho'o.

Bui Lale Kai Wai Ho'o. 
E ... ba fali Baucau:

Buru Uma Kai Bada.

Ba Laga: Soba

Ba Kele Kai: Laku Liu.

Ba Los Palos: Lohele Lalobo.

Ba Tekain Liu:

Derok Hun Uma Klaran

iha Watu Karabau.

\section{Neeba renu antigun Luka la}

barak,

mais ukun too Suai,

Ukun too Tutuala neeba,

too Loro We Masi.

Neeba ema koalia naaka:

Isin lolon rai Luka

reii too Wai Bobo.

Dikur balu We Masi, balu We

Soru.
And ... going to Baucau:

Buru Uma Kai Bada.

To Laga: Soba

To Kele Kai: Laku Liu

To Los Palos: Lohele Lalobo

To Tekain Liu:

Derok Hun Uma Klaran

in Watu Karabau.

The subjects of the ancient kingdom of

Luka were not many,

but they ruled as far as Suai.

They ruled as far as Tutuala

As far as Loro We Masi [Vemasse].

Therefore there is a metaphorical saying:

The buffalo's main body is the land of Luka

Its nose reaches Wai Bobo.

One horn reaches to We Masi [Vemasse], another to We Soru [Vessoru]. ${ }^{23}$

Yet, not all peoples are so concerned with the metaphor of Luca's ritual power. The people of Wai Riu from the peaks of Mundo Perdido challenge the politicoritual accounts of the pre-eminent rule of either Luca or Wewiku-Wehali across the east. In contrast to other houses in their region, which did receive sacred objects such as the sceptre (rota), drum (tamboor), and dances (tebe no bidu) from Luca, the Wai Riu people of Mundo Perdido (Wai Nete Watu Ba'i) assert that their sacra emerged from the same place as them: the waters under the earth. The Wewiku-Wehali, they say, arrived by way of Luca some thirteen generations ago. It was they who brought with them a monarchical system, intermarried with autochthonous clans, and began to rule over the kingdoms of Luca and Viqueque. Others, like Timorese historian Antonio Vicente Marques Soares (who is also a lia nain from Uma Tolu, Lacluta, in Viqueque), maintain that the ritual political centre of Luca emerged as the Tetum Terik speakers of Wewiku-Wehali arrived into a Waima'a-speaking region, which was then loyal

23 A buffalo is being used here metaphorically to explain the territorial power of Luca as the main kingdom: its nose kisses (reii) Wai Bobo (symbolizing the 'east' here), and its two horns symbolize the north and south coasts of the east. 
to the inland domain of Ai Sahe (see also Spillett 1999:348). Meanwhile, in a Makasae narrative version of the regional, hydrosocial cycle, it is ancestral beings coming from across the sea (or, alternatively, from the 'other world') which travel across and populate the land (via, but not beginning in, Luca) (Palmer 2015:61-82).

It is also clear that at whatever point it was that Luca's power expanded across the region, the new houses and spring water sources its emissaries 'created' became sites for rich agricultural groves, allowing critical developments in irrigated rice production (Palmer 2015:129-52). In another story from the southern side of Mundo Perdido, we find a spring, Wai Lesu, whose waters once drained back to its origins in Luca. ${ }^{24}$ The spring takes its name from a lesu (Kairui: a wooden rice-husking implement). In its origin story, the waters emerged from the ground following a lesu being dropped, which was being used beneath the pillars of a sacred house located on a high precipice. After recovering the lesu from the newly emerged spring at the bottom of the precipice, the house of Wai Lesu began making ritual offerings to feed the custodians of the spring. However, at some point in time these rituals ceased and as a result the spring water simply drained back down the mountain to Luca. Arriving back in Luca, the water metamorphosed into human form, and told the ruler of Luca that the people of Wai Lesu no longer respected the spring. Bereft at losing their water source, the people of the house of Wai Lesu sent out a messenger to Luca to negotiate the return of the spring water. The ruler of Luca gave this messenger sacralized betel leaves and told him to return home and prepare for a ritual at the spring. When all the necessary sacrifices had been readied, the messenger of the house 'called' the ruler of Luca at the spring, using his betel leaves: 'Are you [the water] coming yet, or not?', he asked. 'We are coming', was the reply. As the messenger recited a prayer and the sacrificial buffalo fell to the ground dead (a sure indication of the power and correctness of the prayer), suddenly the spring water re-emerged, gushing from the ground to swallow up all the things prepared as an offering (Palmer 2015:55-6).

\section{Water and the Expansion of Luca}

As we have seen above, in spring narratives across the region the politico-ritual kingdom of Luca is repeatedly reported as the 'mother' or power source for

\footnotetext{
24 While in some versions this is said to be a modern-era story, others refer to it as a story of ancient times.
} 
many springs. However, in these watery narrative journeys, Luca's influence over, or creation of, specific springs is usually subsequent to earlier ancestral movements of both people and water. During this earlier time, house-specific ancestral sacra also emerged. As people (and water) spread out across the region, settling in new places and inter-marrying, the sacra connected to particular centres of ritual power also spread through the region. All these waters are understood as being connected to the 'other world', a world often identified with the sea. Yet it was because of Luca's perceived pre-eminent relationship with this other world of the sea that it emerged as the politico-ritual centre of the eastern region of the island (see Palmer 2015:39-60). During this period it was sacra (such as betel leaves and gold) and lulik waters drawn from the springs of Luca that gave its emissaries the right to (re)create new centres of power.

Across the region stories recount how in ancestral times people emerged out of springs ruling themselves, until later coming under the rule of Luca. Other stories tell specific events about the coming of Luca, whose presence is often accompanied by the use of supernatural force connected to the underworld. The people of Wailili, who live on the northern coastal escarpment of Baucau, explain how their political pre-eminence was overthrown at some point by the arrival of a man from the kingdom of Luca. Denied marriage with a local woman, this man returned to Luca to collect a bamboo-length of water. On his arrival back to Wailili he threw this water on the ground by the woman's family home. This triggered an eruption of subterranean waters, which swallowed the hamlet in its entirety, drowning the people and creating a new spring known as Ira Luca. ${ }^{25}$ This man, Dukai from Luca, is characterized in ritual verse as seeking to control everything, from the mountains to the sea (Palmer 2015:83-105).

\section{The Fall of Luca and the Rise of Vemasse}

During the colonial era, as alliances were forged and broken between rulers and the colonial powers, indigenous systems of exchange and alliance became aligned with 'tribute' payments to 'foreign' rulers (compare with Forman 1978). Oral histories recount how local agricultural and woven products were important in the indigenous and colonial systems of tribute, exchange, and power relations. In these exchanges, kingdoms such as Luca returned to their 'vassals'

25 We know of at least five other, similar stories from localities in the central eastern region (in Venilale, Berecoli, Cairiri, Wailili, and Lacluta). 
the symbols of the right to rule, such as sacred golden disks (belak), headdresses (kaebauk), sacralized betel nuts (bua malus), sacralized waters, and, eventually, the Portuguese sceptre (rota). According to Forman (1978), this confluence of indigenous and foreign systems of exchange and alliance-making was a central element of the political and moral transition to Portuguese rule.

Prior to this, Baucau, a place of minor political importance until the early 190os, was under the rule of Luca. According to the oral histories, at some point Luca lost its power and its rulers retreated back across the mountains in shame. As a result much of the water retreated, too. Another oral history, told in the Baucau village of Bahu, recalls the fate of a despotic ruler called Dom Bastião (Sebastião is a name synonymous in the east with colonial-era rulers from Luca). At around the same time as the colonial capital was moved from Lifau to Dili (1769), this ruler's interference with young women in Baucau led to the local population taking the decision to bury him alive with his slaves deep in an underground crevice in central Baucau. The story also correlates with the period during which Vemasse was rising to regional prominence, having received the rota directly from the Portuguese rather than via Luca. In the late nineteenth century, colonial rulers from Vemasse and Laleia increased their influence over the houses of Baucau. Despite this shift in allegiance, Luca remains until the present a 'big name' in Baucau and across the east (see Palmer 2015:106-28).

\section{Conclusion}

Going against the conception of a 'clean break' (De Certeau 1986:4) between the past and the present, in historical narratives memory entangles the past with the present, and brings it to presence (Attwood 2011:178; compare with Chakrabarty 2011). So, too, as we have seen, does myth and its ritual performance. As Gow (2001:285) writes:

myths are casually related to history but, when threatened with historical events which would render them meaningless, they simply transform, in order to preserve themselves from such meaninglessness [...] In this reaction to a changing world, myths obliterate time [and] act to reset the temporal scale of the lived world [creating with it] new sets of meaningful connections to be explored and lived.

In this way, these narratives are constantly semantically re-interpreted to form the basis of dynamic, relational, actual worlds (Boucher 2013). They suggest that 
Luca was more of a 'kingdom of words'. Partly paralleling the 'cosmic' model of kingship found elsewhere in Southeast Asia, it maintained claims to centrality in an East Timorese context which led to widely different assessments by outsiders: from the nineteenth-century Dutch assertions of its paramountcy to the dismissive attitude of some late-colonial Portuguese observers. Under certain circumstances, most notably in the Guerra dos Doidos, the myths of Luca's status could be activated and channelled into major anti-colonial movements which the Dili authorities were unable to deal with efficiently. There are parallels here with, for example, the impact in the Malay world of Minangkabau activists in the 1680 s and 1710 , and the Dutch failure to subdue Klungkung in 1849-in both cases the Dutch colonizers underestimated the ideas of mystic power associated with the conventionally weak kingdoms of Pagaruyung and Klungkung (Drakard 1999:187-208; Wiener 1995:183-221).

Yet, as we have shown, this mystical power does not emanate only from the centre. It is re-enforced and underpinned by deep cosmological understandings that seamlessly refashion narratives of place and power to accommodate historical contingencies and reinvigorate present-day contexts. By disrupting incipient forms of statecraft emanating from Wewiku-Wehali (and extending to Luca), the Portuguese influence in eastern Timor over time both contributed to, and broke down, the pre-eminent politico-ritual importance of its various and vacillating regional kingdoms. Yet, the living tradition amply demonstrates Luca's ongoing importance in localized narrative histories and ritual practices associated with water. In the new nation-state of Timor Leste (2002-present), away from the historical and present-day machination of state rule and party-political power, localized Timorese claims to place and power continue to resonate around clan identities and histories with deep Austronesian and Melanesian influences. These localized social structures and shifting alliances are based on the continued activation and honouring, through ritual, of meshworks of place-centred cosmic power and inter-relationships between people and their ancestral domains. What is significant about Luca in this sense is that its status as a source of politico-ritual power has, in both words and ongoing ritual practice, at least to some extent survived the material changes of the last two centuries. It is, we argue, precisely because Luca's deeper meaning and import as a politico-ritual domain is so geographically slippery and temporally elusive that it cannot be pinned down once and for all in either historical or mythical realms. Yet while its specific form continues to elude us, its presence, as we have shown, is always there, lingering in the historical shadows and providing 'shade' to the localized ancestral domains that once came within its ambit. By piecing together these strands of history, myth, and practice, we hope to have brought this lingering 'shade' and presence some way into the light. 


\section{Dedication}

We would like to dedicate this article to the memory of Antonio Vicente Marques Soares (1947-2016), a great historian and lia nain of the island of Timor.

\section{References}

\section{Archives}

Koninklijk Instituut voor Taal-, Land- en Volkenkunde (KITLV) Archive, Leiden.

Nationaal Archief, The Hague, Archive of the voc, 1.04.02.

\section{Published Sources}

Attwood, B. (2011). 'Aboriginal history, minority histories and historical wounds: The postcolonial condition, historical knowledge and the public life of history in Australia', Postcolonial Studies 14-2:171-86.

Belo, Dom Carlos Filipe Ximenes (2013). Os antigos reinos de Timor-Leste: Reys de Lorosay e reys de Lorothoba, coronéis e datos. Porto: Porto Editora.

Boucher, G. (2013). 'Disclosure and critique', paper presented at Multiple Ontologies/ Ontological Relativity Workshop, Deakin University, Melbourne, December.

Bovensiepen, J. (2012). 'Words of the ancestors: Disembodied knowledge and secrecy in East Timor', Journal of the Royal Anthropological Institute 20:56-77.

Castro, Alfonso de (1867). As possessões Portuguezas na Oceania. Lisboa: Imprensa Nacional.

Census (2010). Census of population and housing. Dili: Direcção Nacional de Estatística and United National Population Fund.

Certeau, M. de (1986). Heterologies: Discourse on the Other, translated by Brian Massumi. Manchester: Manchester University Press.

Chakrabarty, D. (2011). 'The politics and possibility of historical knowledge: Continuing the conversation', Postcolonial Studies 14-2:243-50.

Davidson, Katharine G. (1994). The Portuguese colonisation of Timor: The final stage, 1850-1912. [PhD thesis, University of New South Wales.]

Drakard, Jane (1999). A kingdom of words: Language and power in Sumatra. Selangor: Oxford University Press.

Durand, Fréderic (2006). Timor: 1250-2005. 750 ans de cartographie et des voyages. Toulouse: Arkuiris.

Eredia, Manuel Godinho de (1997). Eredia's description of Malaca, Meridional India, and Cathay. Kuala Lumpur: MBRAs.

Forman, S. (1978). 'East Timor: Exchange and political hierarchy at the time of the European discoveries', in: K. Hutterer (ed.), Economic exchange and social interaction 
in Southeast Asia: Perspectives from prehistory, history, and ethnography, pp. 97112. Ann Arbor, MI: Center for South and Southeast Asian Studies, University of Michigan.

Fox, James J. (1971). 'A Rotinese dynastic genealogy: Structure and events', in: T. Beidelman (ed.), The translation of culture, pp. 37-77. London: Tavistock.

Fox, James J. (1980). 'Retelling the past: The communicative structure of a Rotinese historical narrative', Anthropology 3-1:56-66.

Fox, James J. (1995). 'Installing the "outsider" inside: The exploration of an epistemic Austronesian cultural theme and its social significance', paper presented at the First Conference of the European Association for Southeast Asian Studies 'Local Transformation and Common Heritage in Southeast Asia', Leiden University.

Francillon, Gerard (1967). Some matriarchic aspects of the social structure of the southern Tetun of Middle Timor. [PhD Thesis, ANU.]

Freycinet, Louis de (1825). Voyage autour de monde. Paris: Pillet Ainé.

Geertz, Clifford (1980). Negara: The theatre state in nineteenth-century Bali. Princeton: Princeton University Press.

Gow, P. (2001). An Amazonian myth and its history. Oxford: Oxford University Press.

Gunn, G.C. (1999). Timor Loro Sae: 500 years. Macau: Livros do Oriente.

Gunter, J. (2008). 'Violence and "being in history" in East Timor: Local articulations of colonial rebellion'. [MA thesis, Instituto Superior de Ciencias do Trabalho e da Empresa, Instituto de Ciências Sociais da Universidade de Lisboa.]

Hägerdal, Hans (2012). Lords of the land, lords of the sea: Conflict and adaptation in early colonial Timor, 1600-180o. Leiden: KITLv Press.

Hamilton, Roy. W. \& Barrkman, Joanna. (2014) Textiles of Timor: island in the woven sea, Fowler Museum at UCLA, Los Angeles.

Hicks, D. (2004) [1976]. Tetum ghosts \& kin: Fertility and gender in East Timor. Illinois: Waveland Press.

Kehi, B. and L. Palmer (2012). 'Hamatak Halirin: The cosmological and socio-ecological roles of water in Koba Lima, Timor', Bijdragen tot de Taal-, Land- en Volkenkunde 168:445-71.

Leitão, H. (1952). Vinto e oito anos de história de Timor (1698 a 1725). Lisboa: Agência Geral do Ultramar.

Lombard-Jourdan, Anne (1982). 'Un mémoire inédit de F.E. de Rosily sur l'île de Timor (1772)', Archipel 23:91-133.

McWilliam, Andrew (2002). Paths of origins, gate of life: A study of place and precedence in southwest Timor. Leiden: KITLV Press.

Matos, Artur Teodoro de (1974). Timor Português 1515-1769: Contribuição para a sua história. Lisboa: Faculdade de Letras da Universidade de Lisboa.

Palmer, L. (2015). Water politics and spiritual ecology: Custom, environmental governance and development. Abingdon: Routledge. [Routledge Explorations in Environmental Studies.] 
Panão, A. (1920). 'Timor: Esboço Histórico—o que anda na tradição oral dos povos que demoram a leste da ilha', Revista Colonial.

Pélissier, René (1996). Timor en guerre: Le crocodile et les Portugais (1847-1913). Orgeval: Pélissier.

Roque, Ricardo (2010). Headhunting and colonialism. Anthropology and the circulation of human skulls in the Portuguese Empire, 1870-1930. Cambridge: Palgrave Macmillan.

Sahlins, M. (2008). 'The stranger-king or, elementary forms of the politics of life', Indonesia and the Malay World 36:177-99.

Santa Catharina, Lucas de (1866). História de S. Domingos. Quarta parte. Lisboa: Panorama.

Schulte Nordholt H. (1971). The political system of the Atoni of Timor. The Hague: Nijhoff. Silva, A.B. da (2004). Potential of education for conflict transformation and identity reconstruction in the cultural context of Uato-Lari and Uato-Carbau. Baucau: Instituto Católico Para Formação de Professores.

Soares, António Vicente Marques (2003). Pulau Timor: Sebuah sumbangan untuk sejarah. Baucau: Matebian Press.

Spillett, Peter (1999). 'The pre-colonial history of the island of Timor together with some notes on the Makassan influence in the island'. Darwin: Museum and Art Gallery of the North Territory. [Unpublished manuscript.]

Teixeira, Manuel (1957) Macau e a sua diocese IV. A diocese de Malaca. Macau: Tip. do Orfanato Salesiano.

Temminck, C.J. (ed.) (1839-1844). Verhandelingen over de natuurlijke geschiedenis der Nederlandsche Overzeesche Bezittingen. Leiden: La Lau.

Therik, Tom (2004). Wehali, the female land: Traditions of a Timorese ritual centre. Canberra: ANU, Pandanus Books.

Thomaz, L.E.F.E. (1981). 'The formation of Tetun-Praça, vehicular language of East Timor, in: Nigel Phillips and Khaidir Anwar (eds), Papers on Indonesian languages and literatures. London: Indonesian Etymological Project; Paris: Association Archipel. [Cahiers d'Archipel 13.]

Traube, E. (1989). 'Obligation to the source: Complementarity and hierarchy in an eastern Indonesian society', in: D. Maybury-Lewis and U. Almagor (eds), The attraction of opposites: Thought and society in the dualistic mode. Ann Arbor: University of Michigan Press.

Visser, B.J.J. (1934). Onder de Compagnie: Geschiedenis der Katholieke missie van Nederl.Indië, 1606-180o. Batavia: Kolff.

Wellen, Kathryn Anderson (2014). The open door: Early modern Wajorese statecraft and diaspora. DeKalb: Northern Illinois University Press

Wiener, Margaret J. (1995). Visible and invisible realms: Power, magic and colonial conquest in Bali. Chicago and London: University of Chicago Press. 